\title{
30. GEOCHEMISTRY OF SEDIMENTS FROM THE PERU UPWELLING AREA: RESULTS FROM SITES 680, 682, 685, AND 6881
}

\author{
Marta T. von Breymann, ${ }^{2}$ Kay-Christian Emeis, ${ }^{2}$ and Angelo Camerlenghi ${ }^{2}$
}

\begin{abstract}
Sediments from four sites drilled during Ocean Drilling Program (ODP) Leg 112 exhibit chemical variability that distinguishes diatomaceous muds in shallow water (Site 680) from those muds of deeper water (Sites 682,685 , and 688). Differences in the concentrations of elements precipitated or mobilized during epigenesis and diagenesis, in particular barium abundance, show promise as indicators for depositional environment. The distribution of barium is related to detrital components in Site 680 and related to epigenetic and diagenetic processes in deep-water sites (Sites 682, 685, and 688), making it a potential indicator for water depth in siliceous, organic carbon-rich sediments. Bromine abundance relative to organic carbon may be inversely related to the age of the sections. We document that bromine (in solids) and bromide (in dissolved) phases do not behave conservatively, but that they are instead related to organic matter remineralization. On the basis of differences in the abundances of detrital and diagenetic components, we can statistically discriminate between the shelf and slope deposits of the Peru forearc basins. A significant deficit in detrital accumulation is apparent in upper Miocene through Pliocene sediments at Sites 682 and 685 on the lower slope, as compared to a steady, if erratic, increase of detrital influx during the Pleistocene. Our data on the concentration of elements in the detrital component on the lower-slope sediments further suggest that substantial sources of clastic material deposited on the lower slope have not yet been identified, because published estimates of river runoff and clastic sedimentation on the upper slope and shelf fall short by at least an order of magnitude.
\end{abstract}

\section{INTRODUCTION AND SCIENTIFIC OBJECTIVES}

A section approximately $50 \mathrm{~km}$ wide, in a water depth of up to $500 \mathrm{~m}$, that extends from $6^{\circ}$ to $14^{\circ} \mathrm{S}$, parallel to the coast of Peru, is one of the major areas of biogenic carbon production and burial in the world ocean. A series of forearc basins underlies the upper slope and the shelf, which in some cases (i.e., Pisco Basin, Lima Basin, Fig. 1) experienced tectonically induced subsidence of up to $500 \mathrm{~m} / \mathrm{m}$.y. since the middle Miocene, thus creating receptacles for at least part of an immense sediment load (Kulm et al., 1981, Suess, von Huene, et al., 1988). In other cases, (i.e., the Talara, Yaquina, and Trujillo basins), subsidence was sporadic or missing, and sediment records here are incomplete or compressed. Suess et al. (1987) estimated that $2.2 \times 10^{13} \mathrm{~g}$ organic carbon are annually produced over the Peru shelf, of which approximately $22 \times 10^{10} \mathrm{~g}$ organic carbon are buried in the sediments; this is approximately $0.24 \%$ of all marine organic matter buried annually (Romankevich, 1984). Short-term rates of primary production may reach up to $5 \mathrm{~g}$ organic carbon $/ \mathrm{m}^{2} / \mathrm{d}$, and it is not surprising that sedimentation rates of up to 340 $\mathrm{cm} / \mathrm{k}$.y. have been determined in the depositional centers on the shelf break (Koide and Goldberg, 1981).

Terrigenous sediment components accumulate at rates between 10 and $50 \mathrm{~g} / \mathrm{m}^{2} / \mathrm{yr}$, and the total annual accumulation rate for the shelf and upper slope mud lens, according to Scheidegger and Krissek (1983), is between 2.5 and $12.6 \times$ $10^{12} \mathrm{~g} / \mathrm{yr}$. These scientists claimed that most, if not all, of the annual terrestrial suspended matter in streams discharging into the area between $10^{\circ}$ and $14^{\circ} \mathrm{S}$ (i.e., $4.9 \times 10^{12} \mathrm{~g} / \mathrm{yr}$ ) is retained by biogenic compaction and is deposited in the mud lens of the outer shelf and upper slope.

${ }^{1}$ Suess, E., von Huene, R., et al., 1990. Proc. ODP, Sci. Results, 112: College Station, TX (Ocean Drilling Program). 77840 .
Our objective for this study was to examine the geochemical character of sediments from the Peru upwelling area, which are analogous in facies and origin to such deposits as the Monterey and Pisco formations, and thus to sediments of considerable hydrocarbon potential. We were interested in discerning differences in depositional conditions (such as changes of terrigenous influx through time), in finding chemical differences between slope and shelf sediments, and in evaluating the effect of diagenesis on the distribution of diagenetically mobilized elements. We chose to investigate Sites 680,682, 685, and 688, drilled during Leg 112 (Suess, von Huene, et al., 1988), because the sediments recovered there conform both to deposits of primary upwelling-related deposition on the shelf in the center of the present-day mud lens (Site 680 ) and to the secondary depositional center on the lower slope (Sites 682, 685, and 688; Fig. 1). In the lower-slope basins, material resuspended from the shelf and upper slope has been redeposited, which raises the question whether the mass-balance calculation of Scheidegger and Krissek (1983) and their conclusion that the shelf and slope retain the detrital influx from land are valid for the entire time covered by the geological record since the Oligocene.

Because of the longer residence time in the water column, because of prolonged exposure to early diagenetic and epigenetic processes, and because of different depositional conditions, the chemical character of the recycled sediments should be different from that of sediments deposited beneath centers of coastal upwelling. All sites accumulated similar organic carbon-rich diatomaceous oozes and muds throughout the Miocene to Holocene, but sedimentological and faunal evidence show considerable differences in depositional conditions, accumulation rates, and paleowater depth at the individual sites (Suess, von Huene, et al., 1988). Conditions that ostensibly differ in our study area and that may be imprinted on the sediments under examination are (1) biological activity in the upper water column, (2) water depth, (3) suspended particle distributions and their scavenging action during trans- 


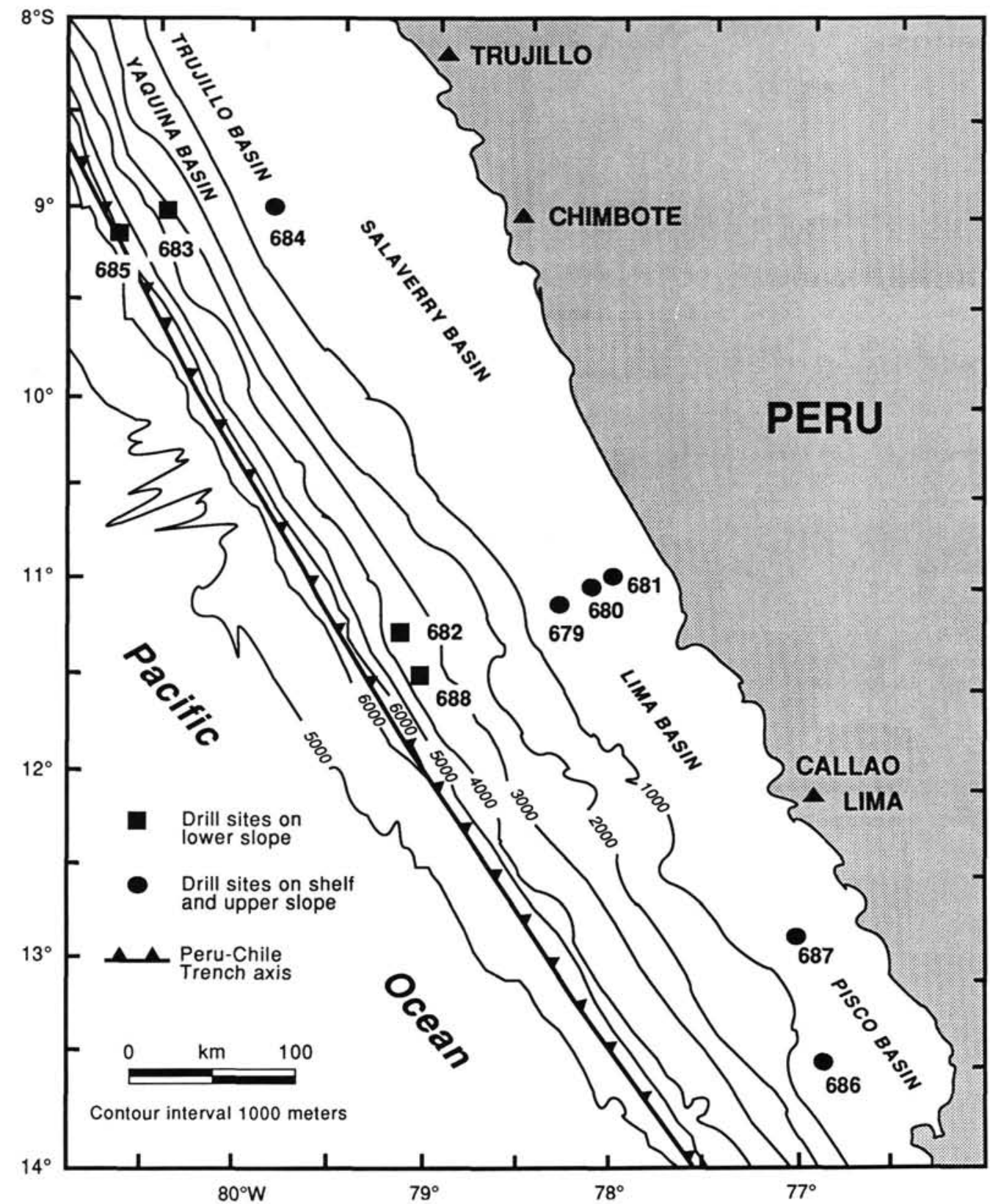

Figure 1. Location of Leg 112 drill sites in the forearc basins offshore Peru.

port to the sediments, and (4) reactions at the sediment/water interface. However, to use these potential indicators of paleoenvironmental conditions, we have to understand their diagenetic behavior. The extreme diagenetic environment in the organic carbon-rich sediments at all sites (Suess, von Huene, et al., 1988) facilitates recognition of diagenetic processes, because the zone of microbial activity and diagenetic mineral formation reactions is greatly expanded, compared to normal marine sediments, and because organic-matter remineralization is an ongoing process throughout the entire sedimentary column.

Our observations and conclusions are based on data obtained by instrumental neutron activation, as well as the reduced-sulfur and opal and organic matter analyses that were reported by Emeis et al., (this volume). In some instances, analysis of dissolved pore-water constituents (barium and bromide) have also been included. While this methodology restricts the range of parameters measured and excludes many chemical elements and compounds (e.g., transition metals), we are confident that we covered the major groups of sedimentary components, e.g., those of biogenic, detrital, and diagenetic origin. In the short time available for interpretation and data analysis, we concentrated on a few subjects of particular interest for describing the character of diatomaceous muds in the depositional centers of the Peru margin. These subjects are (1) the chemical character of sediments from the shelf and the lower slope and their differences, (2) changes in the detrital influx through the geological record since the Miocene, and (3) indications for diagenetic control of barium and bromine concentrations in the sediments.

Before we present the results of our investigation, the geological and depositional settings of the sites under investigation, as given in Suess, von Huene, et al. (1988), are briefly recounted in the following paragraphs. 

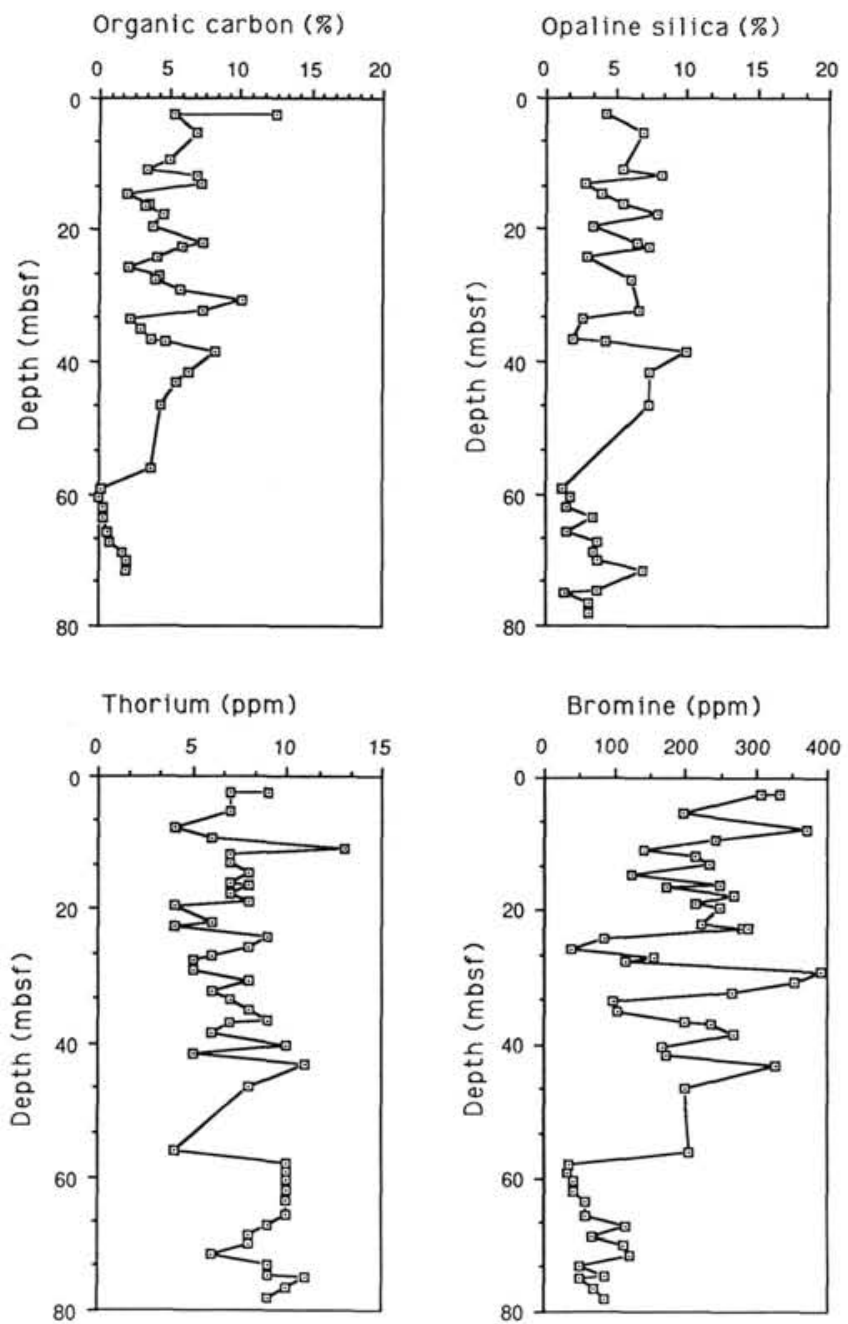

Figure 2. Downhole plots of TOC, opaline silica, thorium, and bromine for Site 680 .

\section{Site 680}

Site 680 (Fig. 1) is located in water $250 \mathrm{~m}$ deep in the center of a lens-shaped sediment accumulation of organic carbonrich diatomaceous mudstones. Lithologic Units I and II (0$56.5 \mathrm{mbsf}$ ) are composed of foraminifer-bearing diatomaceous mud and ooze, with alternating laminated and massive intervals; the sedimentation rate of Units I and II is approximately $55 \mathrm{~m} / \mathrm{m} . \mathrm{y}$. Unit III (56.5-195.5 mbsf) is composed of sand, phosphatic sand, and mud. Laminated and diatomaceous intervals occur as intercalations several meters thick. Sedimentation rates in Unit II were around $30 \mathrm{~m} / \mathrm{m} . \mathrm{y}$. and exceeded $100 \mathrm{~m} / \mathrm{m}$.y. in the lower Unit III (Suess, von Huene, et al., 1988). A striking observation at Site 680 , which was similarly encountered at all other sites on the shelf offshore Peru, was the discovery of a hypersaline subsurface brine that provided dissolved ions to fuel continued and extreme diagenesis in the organic carbon-rich sediments (Kastner et al., this volume).

\section{Site 682}

Site 682 is positioned in a water depth of $3788 \mathrm{~m}$ roughly downslope from Site 680 and, in conjunction with Site 688, yielded a sediment section that covers the sedimentary history from the Oligocene to the Holocene. Sediments here, seaward of the shelf and slope mud lens of primary up-
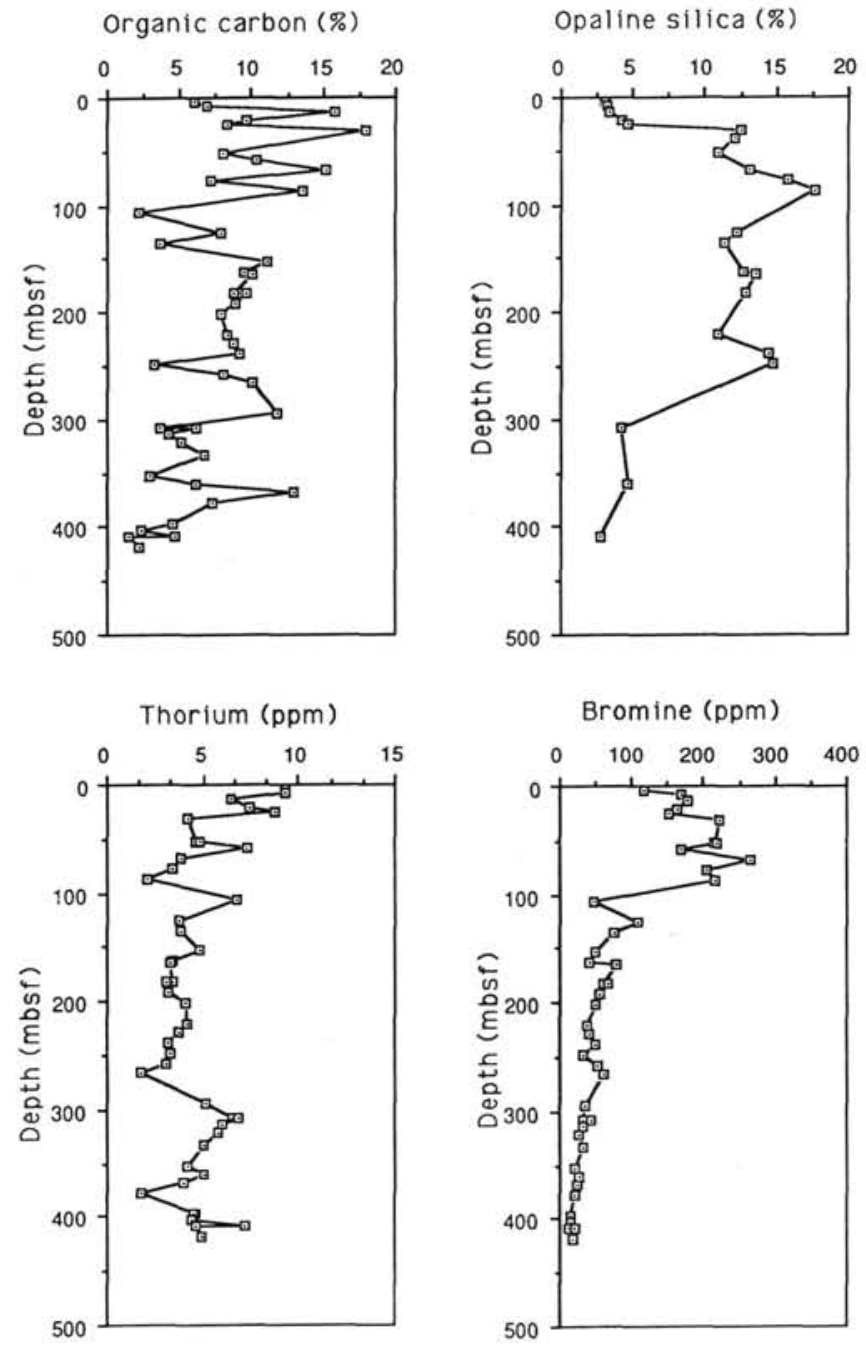

Figure 3. Downhole plots of TOC, opaline silica, thorium, and bromine for Site 682 .

welling-related sediments, record varied water depths and fluctuations in the influence of terrigenous clastics vs. marine biogenic products of upwelling in a middle- and lowerslope depositional center. A section $437 \mathrm{~m}$ thick was divided into four lithologic units. Unit I, of Pliocene to Holocene age, extends from 0 to 114 mbsf and consists of hemipelagic muds having abundant biogenic components, predominantly diatoms. Besides abundant opal and organic matter, these poorly laminated sediments contain terrigenous components, nannofossils, and foraminifers. Benthic foraminifer assemblages indicate that the Pliocene to Holocene sediments were deposited at today's water depth. Unit II (114-311 mbsf), below a hiatus between the Pliocene and upper middle to upper Miocene strata, is more consolidated and is apparently tectonically fractured. Foraminiferal markers indicate a shallower water depth during deposition, and reworked fossil markers suggest that erosion and sediment displacement occurred upslope. Unit III is marked by a facies of coarser, more terrigenous and less diatomaceous mudstones of middle Miocene to early Oligocene age that locally contain volcanic ash. Below Unit III, a major hiatus was noted between the Oligocene mudstones above and the Eocene clastic sediments dominated by silt- and sandstones cemented by carbonates. 

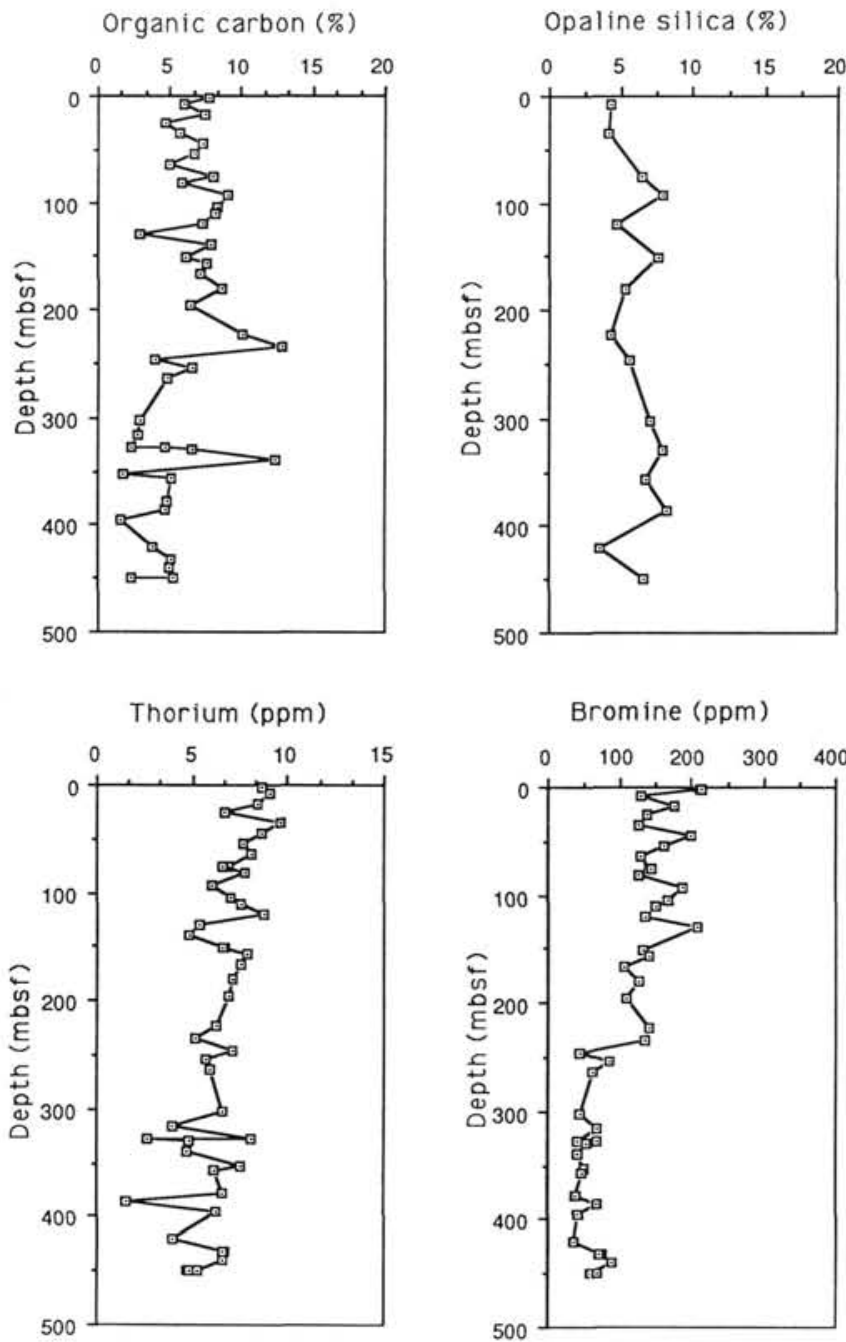

Figure 4. Downhole plots of TOC, opaline silica, thorium, and bromine for Site 685 .

\section{Site 685}

At a water depth of $5070 \mathrm{~m}$, Site 685 (Fig. 1) is a deep-water equivalent of Sites 682 and 688 on the lower slope of the area around $9^{\circ} \mathrm{S}$. Deepest sediments of middle Miocene age were recovered from 203.6 to $468.6 \mathrm{mbsf}$ and make up lithologic Unit II, which was deposited in the time equivalent of a single diatom zone $(6.1$ to $6.8 \mathrm{Ma})$. This unit is separated from overlying Pleistocene and Holocene sediments (0-203.6 mbsf) by a hiatus of roughly $4.3 \mathrm{~m} . \mathrm{y}$. duration. The sediments of Unit I are slope deposits of diatomaceous muds and mudstones that are partially tectonically overprinted. Sedimentation rates in the Quaternary section are greater than $100 \mathrm{~m} / \mathrm{m} . \mathrm{y}$., while rates in the Miocene are at least $380 \mathrm{~m} / \mathrm{m} . \mathrm{y}$.

\section{Site 688}

Site 688 (Fig. 1) is located on the lower slope seaward of Site 680 in water $3820 \mathrm{~m}$ deep. The lithologic units recognized here record progressive subsidence of Site 688 since the Eocene. Lithologic Unit I (0-338.5 mbsf) is of Pleistocene age and is composed of bioturbated diatomaceous mud. Starting from Core 112-688A-9X (82.2 mbsf), sediments in Unit I displayed a black color, presumed to result from metastable iron sulfides, which vanished after a few minutes upon expo-
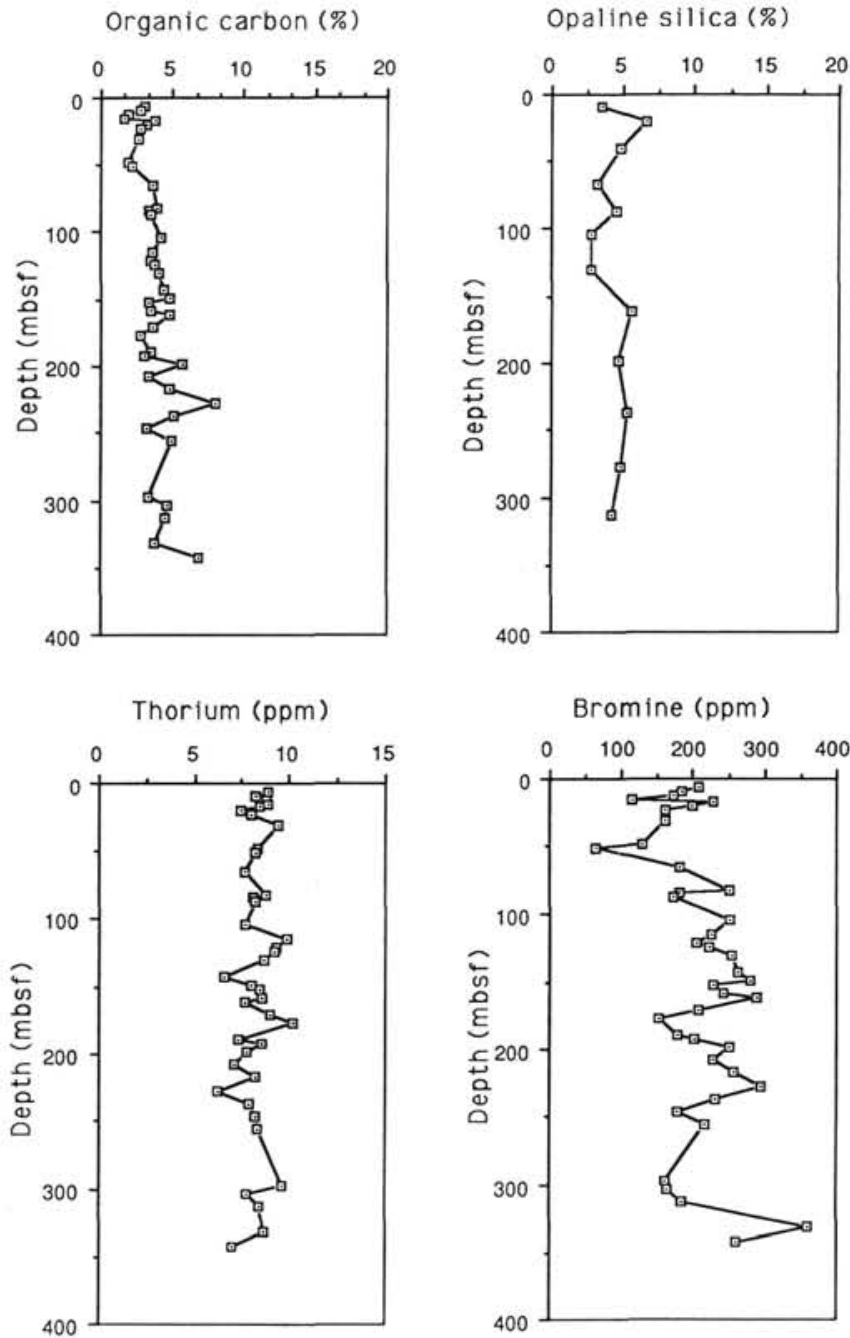

Figure 5. Downhole plots of TOC, opaline silica, thorium, and bromine for Site 688 .

sure to air. Sedimentation rates ranged from 100 to $350 \mathrm{~m} / \mathrm{m}$.y. Upwelling-related sedimentation of diatomaceous ooze and mud since the early Miocene is recorded in lithologic Unit II (338.5-593.0 mbsf), which was deposited at rates from 10 to $50 \mathrm{~m} / \mathrm{m}$.y. Opal-free calcareous and clastic rocks of Unit III of early to middle Eocene age make up the remainder of the section recovered below a pronounced hiatus between upwelling-related diatomaceous lithologies of middle Miocene and younger age.

\section{RESULTS}

The data base used to test our assumption of differing chemical facies was that of Emeis et al. (this volume). Downcore distributions of total organic carbon (TOC), opal, thorium, and bromine are shown in Figures 2 through 5. These elements were chosen because they represent parameters of detrital, biogenic, and diagenetic affinities. We have attempted to distinguish depositional environments on the margin on the basis of factor analysis, because such an approach facilitates recognition of underlying causal relationships and aids one to interpret data (Howarth and Sinding-Larsen, 1983). Statistical analysis was performed using the Systat package on an Apple Macintosh. By factoring the data matrix $(n=179)$ with only those parameters measured at all sites, the rotated loadings of the first two 


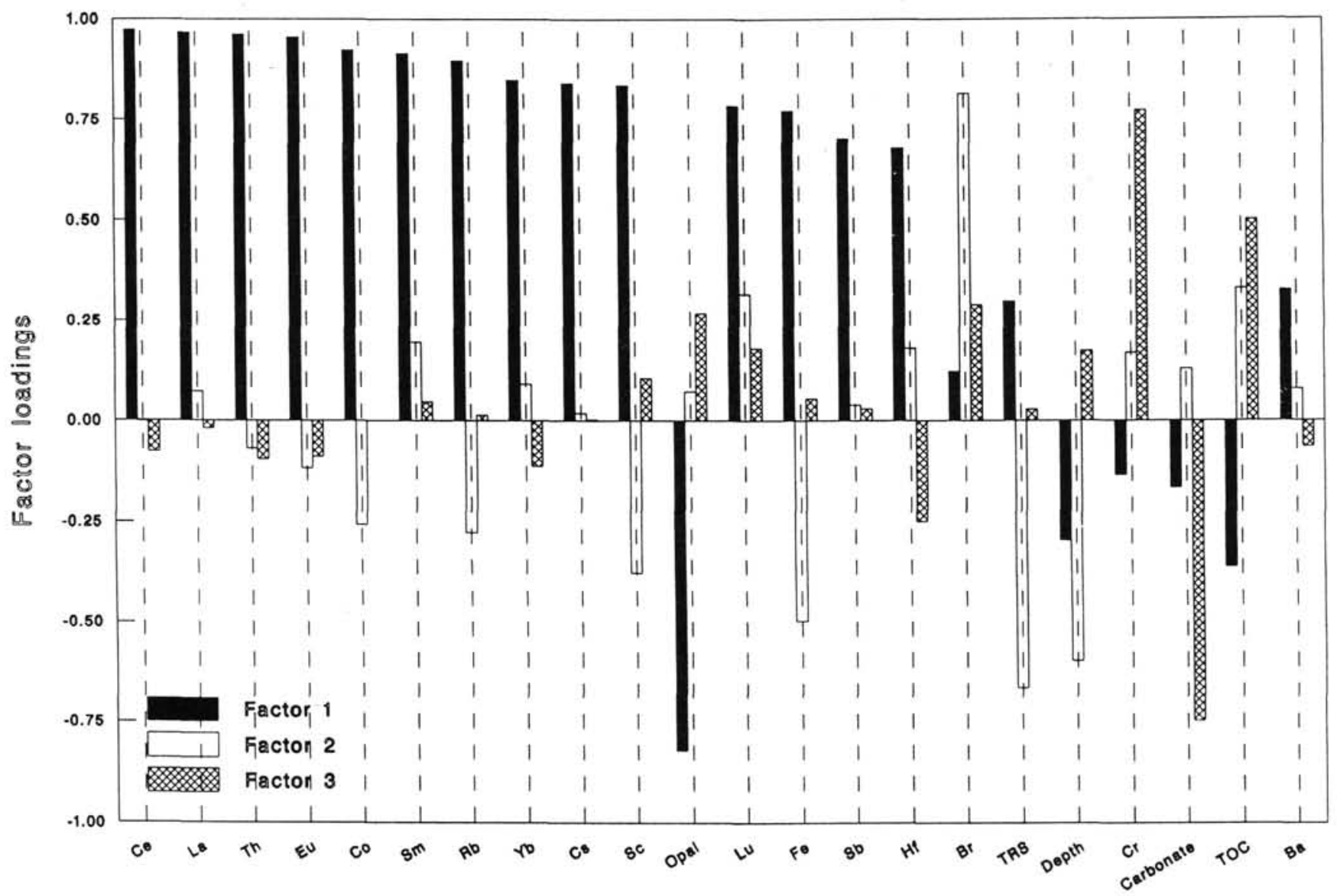

\section{Parameters}

Figure 6. Factor loadings of the parameters measured at each site for all samples studied. Note the coherence and high loadings of the detrital factor 1 of lanthanides, which is offset by negative loadings on opal and TOC. Factor 2 has highest positive loading on bromine, while sulfides (TRS and iron) are negatively loaded.

factors explain a cumulative variance of $63 \%$. Factor 1 , the overwhelmingly dominant factor, has high loadings $(>0.5)$ from elements that are known to correlate highly with detrital material (i.e., lithophilic lanthanides, rubidium, thorium, scandium, and cesium) as well as from siderophile cobalt and iron (Fig. 6). Opal has a highly negative loading on factor 1, and we interpret this antagonism to result from dilution of the clastic component by diatoms.

Factor 2 has high positive loadings on bromine and negative loadings on parameters related to sulfides (iron, TRS) and depth in the sediment column (Fig. 6). We interpret this factor to indicate differences based on diagenetic changes in the sediment. We use the factor scores of all samples on the detrital factor 1 and factor 2 to evaluate the geochemical character of the sediments in the two depositional settings of shelf and slope (Fig. 7). To use more samples for this operation, we deleted opal before factoring. This plot clearly distinguishes Site 680 samples from those of the deep-water Sites 682,685 , and 688 on the basis of the high scores for diagenetic factor 2. Samples from Site 688 are tightly clustered and distinctly different from those of Site 682 , while samples from Site 685 vary between those of Sites 688 and 682 . On the basis of the detrital factor 1 alone, samples from Site 688 appear different from those of Site 682 , with the latter having significantly lower clastic content in those samples that were deposited during the Pliocene and Miocene.

\section{DISCUSSION}

In accordance with the objectives of our study, we focus this discussion on two points that relate (1) to changes in detrital influx through the geological record since the Miocene, and (2) to indications for depositional and diagenetic mechanisms of elements known to be associated with organic matter productivity in the water column. Specifically, we will look at the distributions of barium and bromine in sediments. By contrasting the distributions of elements related to these two distinct sources, we hope to elucidate the changes of detrital and biogenic influx with time and changes in the depositional environment.

\section{The Detrital Component}

The influx of clastic sediment components constitutes a problem of mass balance for the Peru margin. Scheidegger and Krissek (1983) concluded that most of the material produced in upwelling cells over the inner continental margin is actually deposited in prominent mud lenses on shelf and upper slope because of the effectiveness of biological screening and particle transport to the sediment/water interface. Instead, a complex set of depositional and tectonic processes governs the distribution and redistribution of the primarily biogenic remains, as well as the clastic components. Changes in shelf width and morphology, in position of depositional centers and their subsidence, and in relationships between currents and 


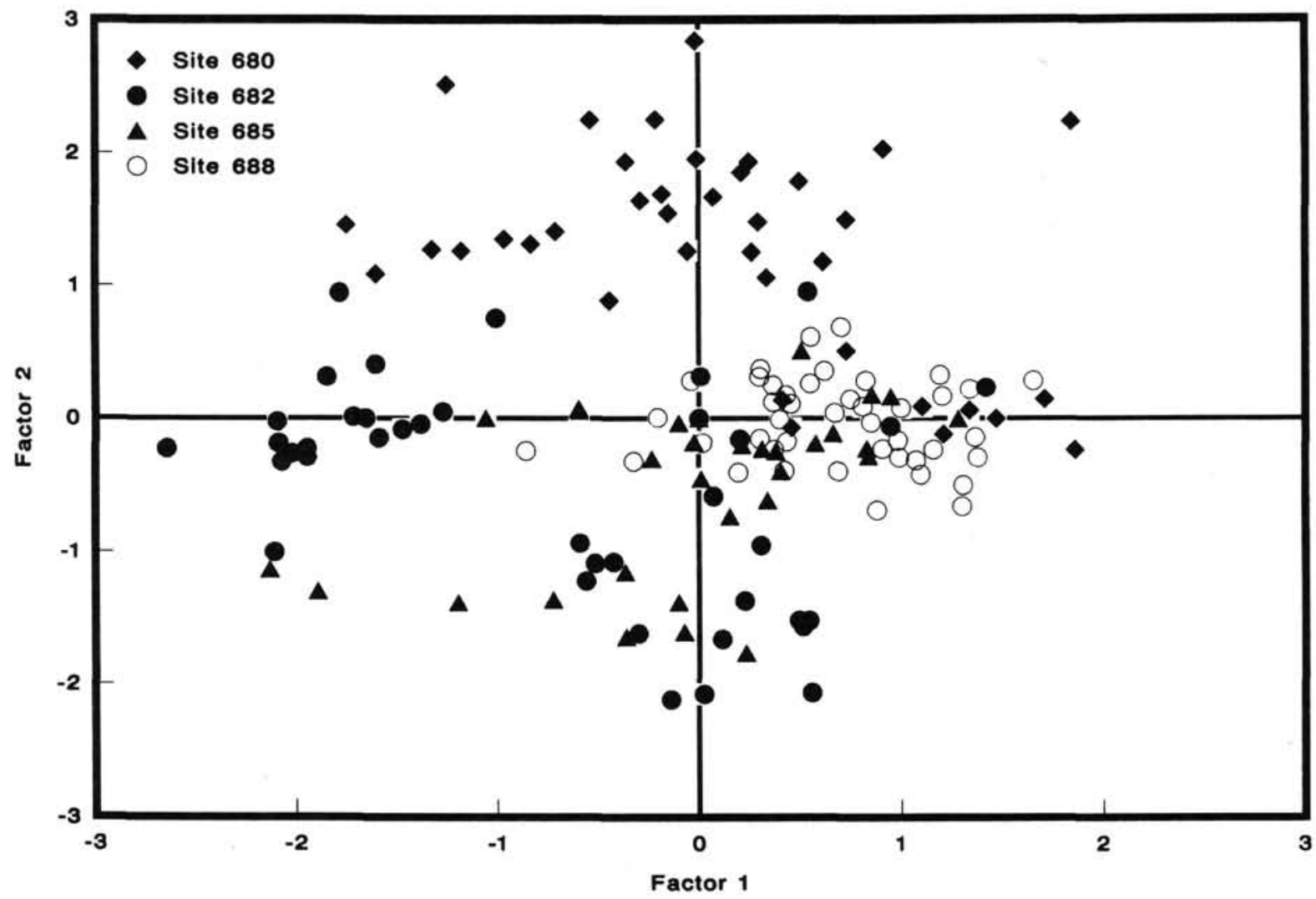

Figure 7. Plot of scores on factor 1 and factor 2 of all data sets (opal was excluded before factoring). Note the good separation of sample populations for the four sites.

depositional areas occurred during the time span covered by sediments obtained during Leg 112 (e.g., Ballesteros et al., 1988). As is the case today, the interplay of morphology (tectonically determined) and hydrography (climatically driven) determined the various sediment facies and their organic matter content in the past. Exposure of sediments to the winnowing effects of poleward-flowing undercurrent (or "poleward-flowing jet" with velocities of up to $25 \mathrm{~cm} / \mathrm{s}$ ) sweeps the wide shelf north of $10^{\circ} \mathrm{S}$ (Suess et al., 1987) clear of fine particles and creates a distinct, more calcareous facies.

Currents are responsible for winnowing and create a facies of coarser-grained calcareous sediments with moderate $(<5 \%)$ organic carbon content on the broad northern sector of the Peruvian shelf (Suess et al., 1987). Current (and possibly wave) action leads to large-scale export of shelf and upperslope sediments, which collect in characteristic lens-shaped mud lenses-the primary depositional centers at the shelf break-to lower-slope basins. Suess et al. (1987) estimated that more than $30 \%$ of the organic carbon primary production in the sector between $6^{\circ}$ and $10^{\circ} \mathrm{S}$ is exported to secondary depocenters $\left(1.2 \times 10^{12} \mathrm{~g}\right.$ carbon/yr). Results from Leg 112, during which several secondary depocenters were penetrated, suggest that this is a conservative estimate, as sedimentation rates are up to 5 times higher on the lower slope than on the shelf at comparable organic carbon concentrations.

Characteristic features of the lower slope are truncated, lens-shaped deposits reminiscent of contourites composed of rather homogeneous biogenic sediments without definite age structure (von Huene and Miller, 1988; Ballesteros et al., 1988). These typical deposits of the lower slope must be reworked deposits from primary depocenters upslope. The following rough mass-balance calculation shows that the low- er-slope area alone may collect as much clastic detritus as does the mud lens upslope. Let us assume that the area characterized by "contourite" deposits ranges from $8^{\circ}$ to $13^{\circ} \mathrm{S}$, i.e., over a distance of about $300 \mathrm{~km}$, and that it occupies the rather narrow strip of approximately $15 \mathrm{~km}$ discernable on four multichannel seismic lines (von Huene, pers. comm., 1988). From seismic investigation and the drilling results of Leg 112, we assume a uniform thickness of $800 \mathrm{~m}$ for this package of middle Miocene to Holocene age, and thus arrive at a mass of $5.6 \times 10^{18}$ $\mathrm{g}$ at a mean bulk density of $1.55 \mathrm{~g} / \mathrm{cm}^{3}$ (Suess, von Huene, et al., 1988). If we also assume conservatively that $50 \%$ of this material is clastic (based on an average of $7 \mathrm{ppm}$ thorium in our data set vs. $11 \mathrm{ppm}$ in average clay [Wedepohl, 1970]), we arrive at a mass of at least $2.8 \times 10^{18} \mathrm{~g}$ for the clastic material in the "contourite" facies of the lower slope. Dividing by 10 m.y. (since the middle Miocene), yields a deposition of $2.8 \times 10^{12} \mathrm{~g} / \mathrm{yr}$ for clastic, terrigenous material. From this, about the same amount of clastic material that was deposited in the outer-shelf mud lens (Scheidegger and Krissek, 1983) may have collected on the narrow lower slope. Even though this calculation does not include other major depocenters, such as the upper-slope basins and the deep-sea trench, major, as yet unidentified, sediment sources may provide sediment to the lower-slope basins in the study area, possibly by lateral transport.

Because we were interested in reconstructing past models of deposition for the sections under investigation, we used biostratigraphic data available from the respective site chapters in Suess, von Huene, et al. (1988) to calculate rough ages for each sample. We assume linear sedimentation rates between datum planes and disregard compaction. In plots of detrital factor scores vs. time for Pleistocene samples of Sites 680 and 688 (Fig. 8), we observed considerable changes in the 


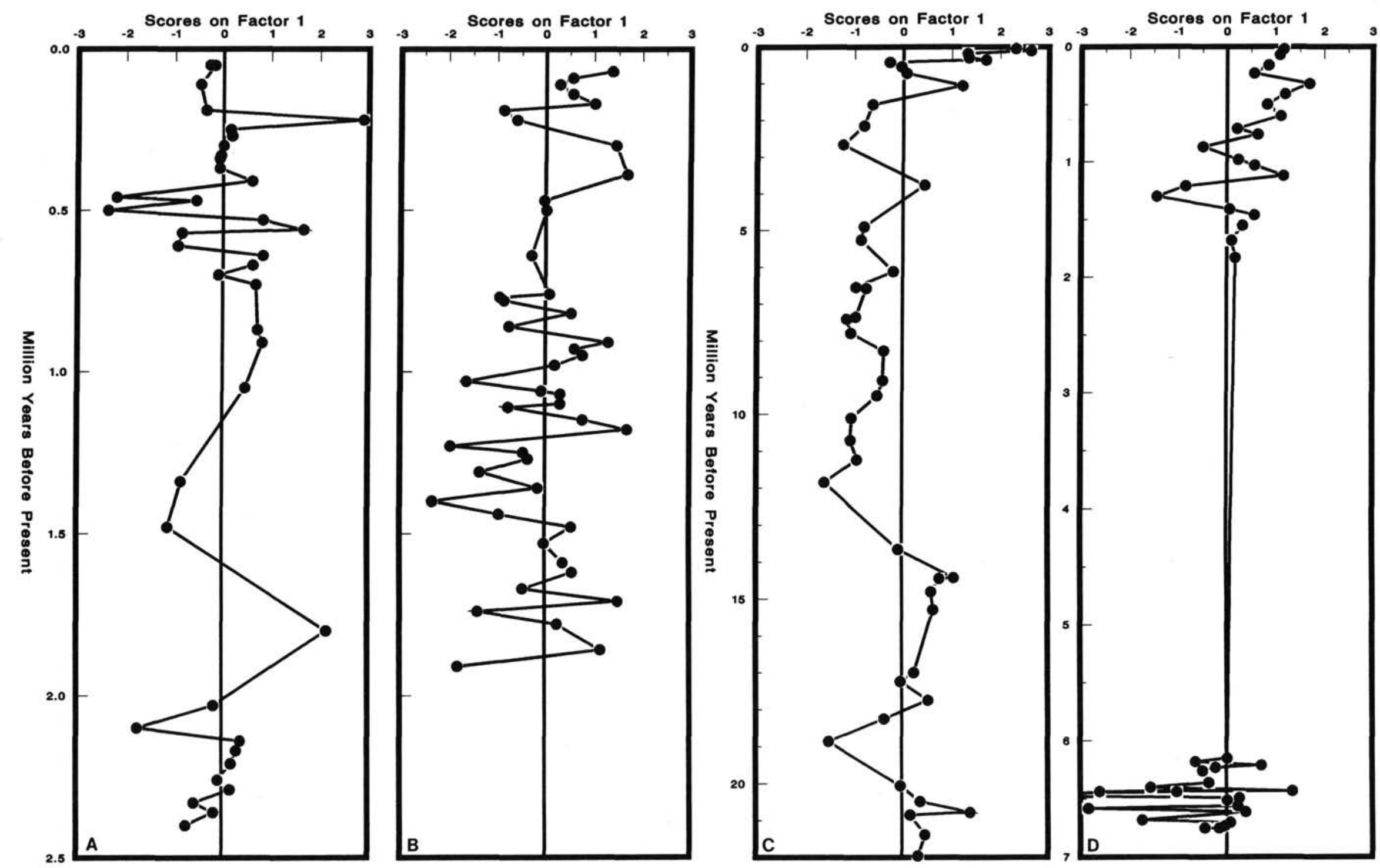

Figure 8. Plots of scores on the detrital factor 1 vs. age (from Suess, von Huene, et al., 1988) for each site. Each data set has been factored individually for this procedure, and sums of scores add up to zero. Sites 680 (A) and 688 (B) extend from the Holocene to the Pleistocene/upper Pliocene. During this time period, the detrital factor shows rapid and erratic changes at the two sites. Sites 682 (C) and 685 (D), both on the lower slope, show an increase in the detrital factor during the Pleistocene, while Pliocene and upper Miocene samples at Site 682 contain relatively 


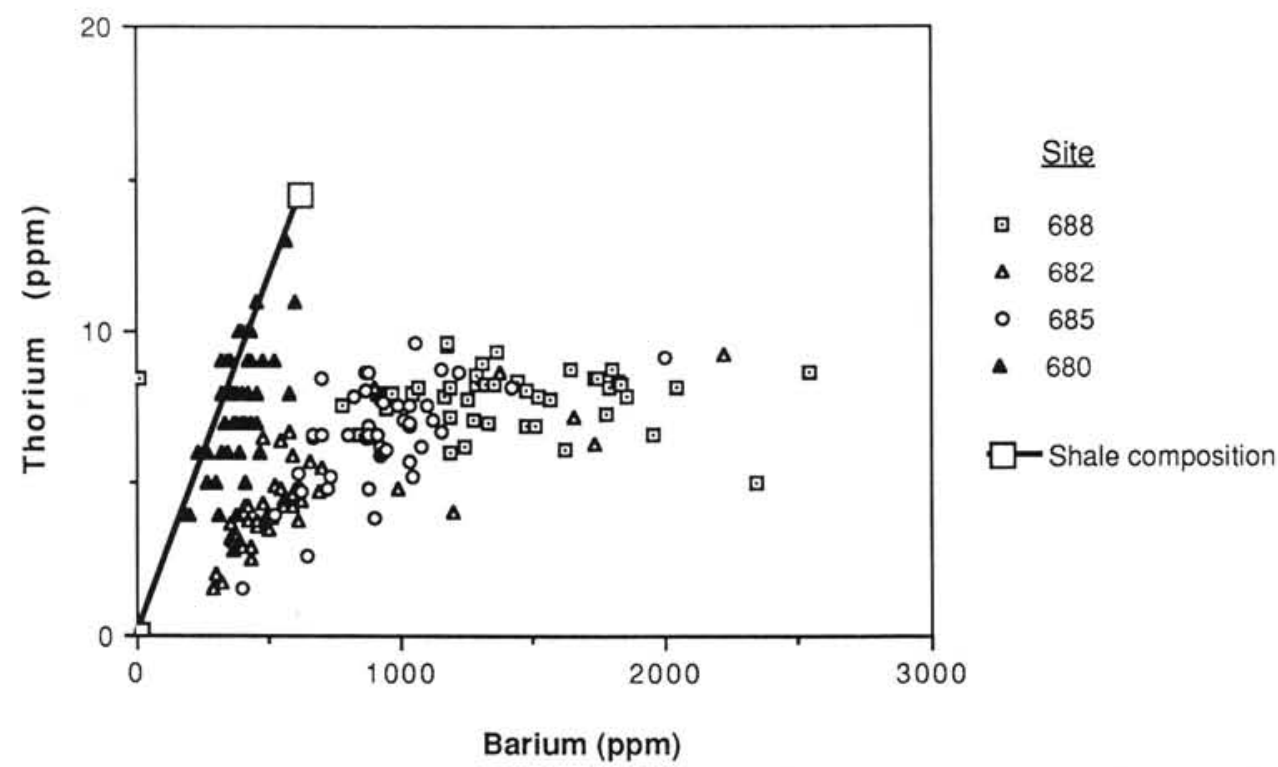

Figure 9. Thorium vs. barium for all samples. Samples from Site 680 correlate highly with the ratio in average shale, which shows that barium in sediments from the shallow site is associated with the detrital fraction. Samples from deep-water sites are relatively enriched in barium. See text for discussion.

detrital influx for the last $2 \mathrm{~m}$.y. Even though these changes may have occurred coherently at both sites, we hesitate to invoke such obvious reasons as sea-level fluctuations and increased terrestrial runoff to explain the variability because of the limitations of our age model. We hope to employ the more-detailed isotope stratigraphy of Wefer et al. (this volume) to calculate accumulation rates of the detrital component in a future study. The age plot of the detrital factor for samples from both Sites 682 and 685 (Fig. 8) gives some insight into the changing detrital supply to depositional centers on the lower slope. In the latter two cases, factor 1 decreases steadily from high values in the late Pleistocene to low values in the Pliocene and upper Miocene. At Site 682, this interval (from about 30 to $300 \mathrm{mbsf}$ ) coincides in part with a slump deposit (lithologic Unit ID) and sediments of lithologic Unit II (114-311 mbsf), which are separated from the slumped section by a hiatus. Benthic foraminifer assemblages in this interval suggest outer-shelf and upper-middle bathyal environments, which implies a considerably shallower water depth at that time (Suess, von Huene, et al., 1988). We speculate that the slumped sediments of low detrital content originated from a primary upwelling center at the shelf break, which must have been shielded against detrital influx by another landward depositional center that may have retained the detritus originating on land. Our data agree with the findings of Clayton and Kemp (this volume), who investigated in great detail the clay mineralogy of the lower-slope and shelf sediments, in that a significant change occurred in the influx of detrital (or rather, lithogenic) material to the sediments of the Peru forearc basins. These scientists found a sharp increase of expandable clay minerals-notably smectite-relative to illite at the base of the Quaternary sections. The dominance of smectite persisted throughout the Pliocene and the upper and middle Miocene. Clayton and Kemp's interpretation for the observed changes in clay mineral assemblages was an increased influx of smectite relative to illite from weathering and devitrification of volcanic material. Our preliminary data, which do not discriminate between qualitative changes in the detrital component, indicate further that the absolute influx of lithogenic and detrital material to the margin was reduced during the Miocene and Pliocene.

\section{Barium Chemistry}

The mechanisms and processes that control the formation, transport, and preservation of barium minerals (notably of barite) in marine sediments have been the subject of numerous studies. Barite formation may be related to biological activity in the upper water column, to decay of organic matter during sinking of nekton, and to dissolution and regeneration at depth (Dehairs et al., 1980; Collier and Edmond, 1984; Bishop, 1988). Barium is enriched in deep-sea diatomaceous oozes (Puchelt, 1972) and in siliceous pelagic clays (Murray, 1987). Bishop (1988) investigated the modes of barite sedimentation in the pelagic realm and concluded that precipitation of barite crystals occurs almost exclusively in microenvironments containing decaying organic matter and diatom debris.

The sediments investigated here offer us an opportunity to examine the concepts of Bishop (1988) because the general abundance of organic matter and opal constitute the type of facies conducive to barium enrichment in these sediments. However, sections have been deposited in different water depths; thus, the influence of water depth on barium accumulation can be evaluated. Figure 9 depicts the relationship of barium to thorium; the latter is a good indicator of the detrital fraction in sediment. Samples from the shelf Site 680 cluster along the line given for average shale (solid line; Wedepohl, 1970). Although there are small deviations from the detrital barium-to-thorium ratio at Site 680 , which might be the result of biogenic sources, the observed distribution suggests that at this site barium content is almost exclusively associated with the clastic fraction of the sediment. By contrast, samples from the slope Sites 682,685 , and 688 are significantly enriched in barium relative to average shale, suggesting a biogenic barium source. This contrasting behavior between the slope and shelf sites deserves special attention because the shelf sediments (Site 680) have organic matter and opal contents comparable in magnitude, or even higher than those of the bariumenriched sites on the slope. Similarly, Calvert and Price (1983) reported a lack of barium enrichment in the opal-rich sedi- 
ments of the Namibian Shelf. Sediment trap data (J. Dymond, pers comm., 1988), as well as dissolved and suspended barium distributions (Chan et al., 1977; Dehairs et al., 1980; Collier and Edmond, 1984) suggest that a significant uptake of barium from the water column occurs below the surface zone of nutrient depletion. These observations suggest that besides siliceous-biogenic productivity, water depth is also a parameter contributing to the accumulation of biogenic barium in sediments (Jumars et al., 1988). This is consistent with Bishop's (1988) proposed mechanism of barite formation during aggregation and settling of siliceous detritus, whereby barite abundance increases during transport below the thermocline. Thus, the observed barium distributions in the shelf and slope sites in the Peru margin are most likely the result of a combination of the effects of siliceous-organic fluxes and residence time in the water column.

Even though we prefer the concept of barium enrichment in the sinking siliceous particles as the source for the high barium concentration in deep-water sediments of the Peru slope (Sites 682, 685 and 688), we have considered the effect of winnowing on the distribution of barite in the Peru forearc basins. Laminations in the shelf mud lens have been attributed to size sorting of biogenic and clastic material. The conspicuous assemblages of monospecific diatoms, or even only their girdle bands, have been viewed as an indication for extreme size- and weight-selective current winnowing $(\mathrm{H}$. Schrader, pers. comm., 1987; see Kemp, this volume, for a discussion about laminations). Conceivably, all particulate barite in the size range of $<1$ to $<5 \mu \mathrm{m}$, the major mode of barite occurrence in suspensions below the euphotic zone (Bishop, 1988), has been resuspended and transported to the lower slope. This selective winnowing would lead to the low, detrital barium levels observed at Site 680 and the enrichment of barium at deeper slope sites.

Figure 10 shows the downhole distribution of the bariumto-thorium ratio in the sediments and of dissolved barium and sulfate in the pore water of the four Leg 112 sites. Sulfate data are those reported by Suess, von Huene, et al. (1988). As stated before, the barium excess relative to the detrital ratio (as indicated by the vertical lines in the barium-to-thorium $[\mathrm{Ba} / \mathrm{Th}]$ profiles) for Sites 682,685 and 688 is probably the result of "biogenic" or epigenetic accumulation of barium at these sites. Consistent with these observations, we also see a steep increase in dissolved barium at Sites 682, 685, and 688, where values reach as much as $98 \mathrm{mM}$. The high concentrations of barium in the interstitial waters of the deep slope sites, contrary to the lack of "biogenic" particulate and dissolved barium at Site 680 , must result from dissolution of some of this biogenic barite under conditions of sulfate depletion. Of note with respect to the lack of dissolved barium in the shelf Site 680 is the unusual distribution of sulfate in the interstitial waters of all shelf sites drilled during Leg 112 (Kastner et al., this volume). After depletion of interstitial sulfate at approximately 50 mbsf at Site 680 , sulfate concentrations increased downhole to values of $37.9 \mathrm{mM}$ at $195.5 \mathrm{mbsf}$ from diffusion/ advection of a hypersaline brine at depth. In contrast to the peculiar hydrological situation on the shelf, interstitial sulfate in sediments of the slope sites (Sites 682, 685, and 688) is depleted in the first tens of meters below the sediment/water interface.

Barium distributions similar to those described here for Leg 112 sites were found by Brumsack and Gieskes (1983) in sediments and pore waters of sediments from the Gulf of California. As in Peru margin sediments, dissolution of barite in the sulfate-depleted intervals of deep-water sections there leads to enrichment of particulate barite near the end of the sulfate-reduction zone, where downward sulfate-diffusion and

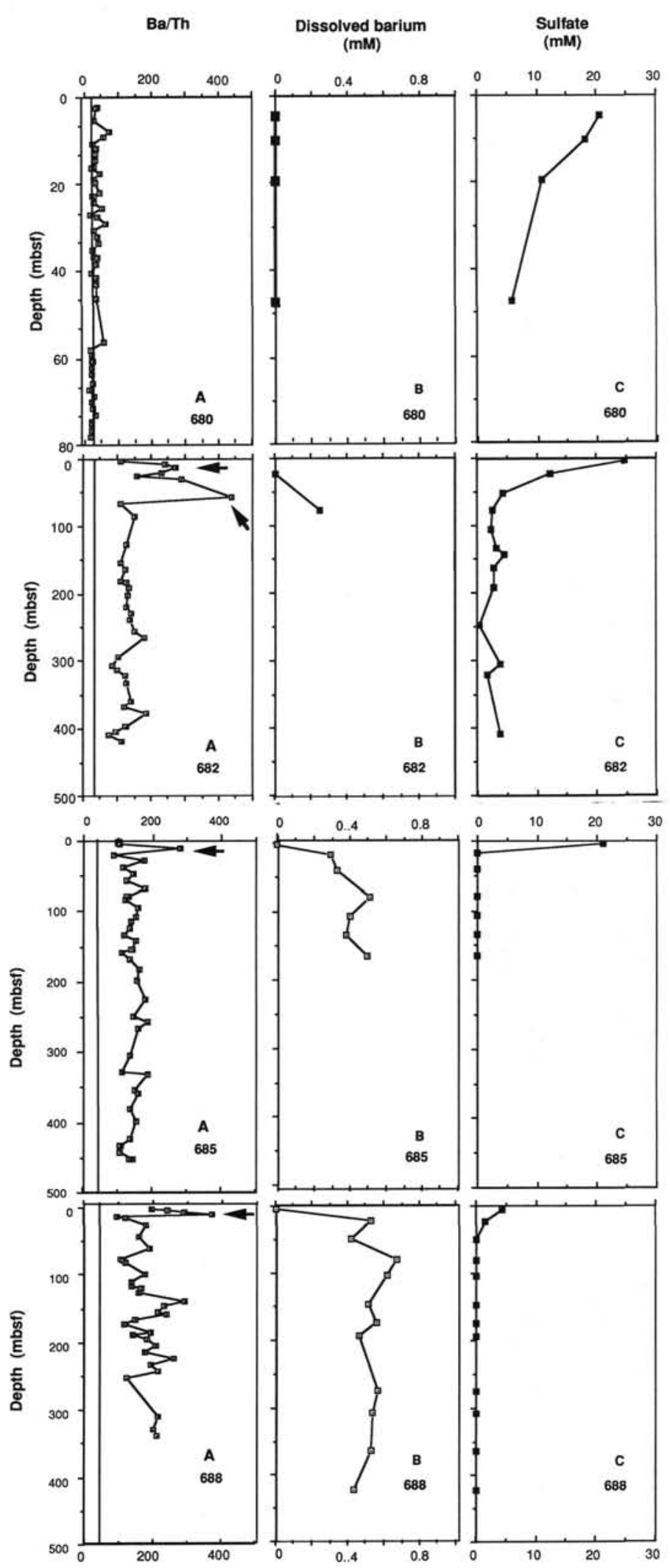

Figure 10. Downhole concentrations of barium in sediments (A), in pore waters (B), and sulfate concentrations in pore waters (C), from Suess et al., 1988). Arrows indicate samples enriched by diagenetic remobilization of barium (see text). 


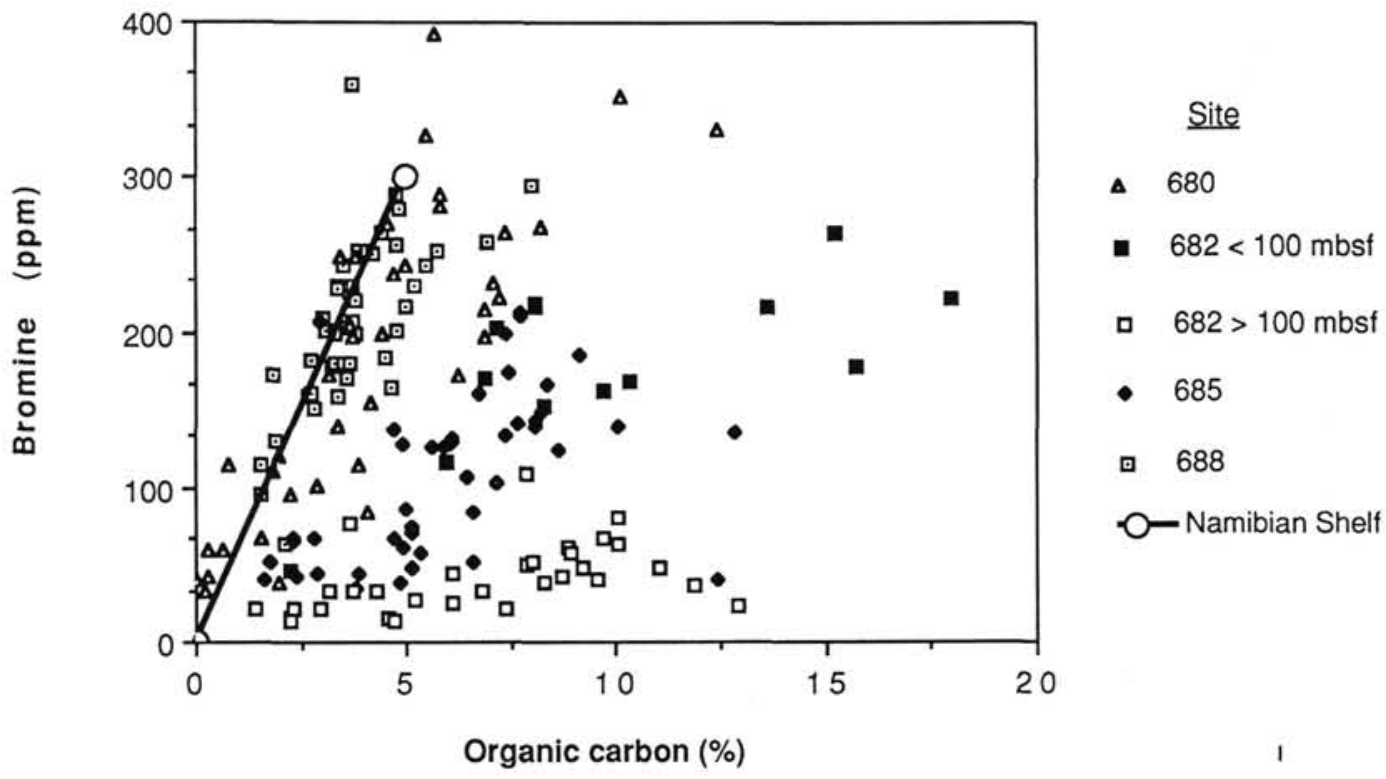

Figure 11. Ratio of bromine to TOC, showing relatively high ratios in sediments of Quaternary age (Sites 688 and 680 ), which decrease with age of the sections. See text for discussion.

upward barium diffusion-fronts foster local barite precipitation. Samples in our downhole plots corresponding to the loci of the barite fronts are marked with arrows in Figure 10. These results imply that the development of "barite fronts" requires a labile barium source, which is not likely to be the barium associated with the aluminosilicate detritus. Although some of the observed excess barium relative to thorium shown in Figure 9 is probably the result of diagenetic remobilization of barium, the original source for this barium must be biogenic.

The development of barite fronts, a phenomenon similar to the well-known metalliferous redox fronts in pelagic sediments, was proposed by Goldberg and Arrhenius (1958) and reiterated by Brumsack (1986) as mechanisms leading to the formation of barite enrichment at chemical boundaries and in lag deposits. It is thus unfortunate, but not surprising, that at Sites 682,685 , and 688 , the barium concentrations in the solid phase exhibit no correlation with either opal or TOC. Our data show clearly that barium should not be used as a proxy for siliceous biogenic influx when reducing diagenetic environments, where sulfate depletion undersaturates the interstitial waters with respect to barite. However, the barium distributions in sedimentary oxic and suboxic environments at deepwater depositional sites still may be good paleoproductivity indicators (Schmitz, 1987; Jumars et al., 1988).

\section{Bromine Geochemistry}

Factor analysis results indicate that bromine distribution in the Peru margin is not governed by the aluminosilicate fraction. This is a common observation in marine sediments (Price et al., 1970), and even when neither the chemical nature of the association of bromine with organic matter nor the mechanism whereby this element is transported to the sediments are well understood, the strong association between bromine and organic carbon in surface sediments has been unambiguously established (e.g., Price and Calvert, 1977; BrongersmaSanders et al., 1980; Pedersen and Price, 1980). Accordingly, factor analysis of data for the four Leg 112 sites shows that bromine correlates with the organic carbon content of the sediments (Fig. 6). However, this relationship is somewhat obscured by post-depositional mobility of bromine. Figure 11 shows the correlation between bromine and organic carbon content for sediment samples from each of the four sites. The relationships vary between sites; Sites 680 and 688, although different in depositional environment, show similar bromine/ TOC ratios. These ratios are similar to those observed for surface sediments from the Namibian shelf (Price and Calvert, 1977). The other sites show a decrease in the bromine/TOC ratios, which reach their lowest levels for the deepest (and oldest) samples from Site 682.

Price and Calvert (1977) reported a decrease in the bromine/TOC ratio with depth in the outer-shelf sediments of the Namibia shelf, which they attributed to bromine mobilization through diagenetic alteration of organic matter. We can observe such a trend in the Peru margin sediments, particularly at Sites 685,688 , and 682 (Fig. 12). Figure 13 shows downhole distributions of dissolved bromide for Sites 680, 685, and 688 . No interstitial water was available for analysis at Site 682 . Note that bromide analyses in pore waters were performed using the colorimetric technique described by Presley (1971). However, recent results indicate that this method is prone to interference from dissolved organic matter in pore water (J. Gieskes, pers. comm., 1989). Nevertheless, we have included these data, even though the absolute values might not be correct, because we are confident that the observed increase of dissolved bromide with depth (Fig. 13) is not artificial. In pore waters from Site 680 we notice a small enrichment of bromide relative to seawater. As the chloride content reflects the hypersaline nature of the fluids at this site, bromide was normalized to chloride to better discern the shape of this bromide enrichment (Fig. 13). Bromide increases at shallow depths within the sediments and indicates a diagenetic mobilization during decomposition of organic matter in the top 20 mbsf (lithologic Unit I). This behavior contrasts with the conservative bromide/chloride ratio of pore water from 20 to 80 mbsf, a sediment section characterized by low TOC content and that is mainly clastic in nature (lithologic Unit II).

Sites 685 and 688 also exhibit significant dissolved bromide enrichments (Fig. 13). These high bromide levels are especially significant when normalized to chloride, because chloride levels are significantly lower than the seawater value at these sites. Both sites show a similar bromide/chloride distribution with depth that we consider further indicates the 

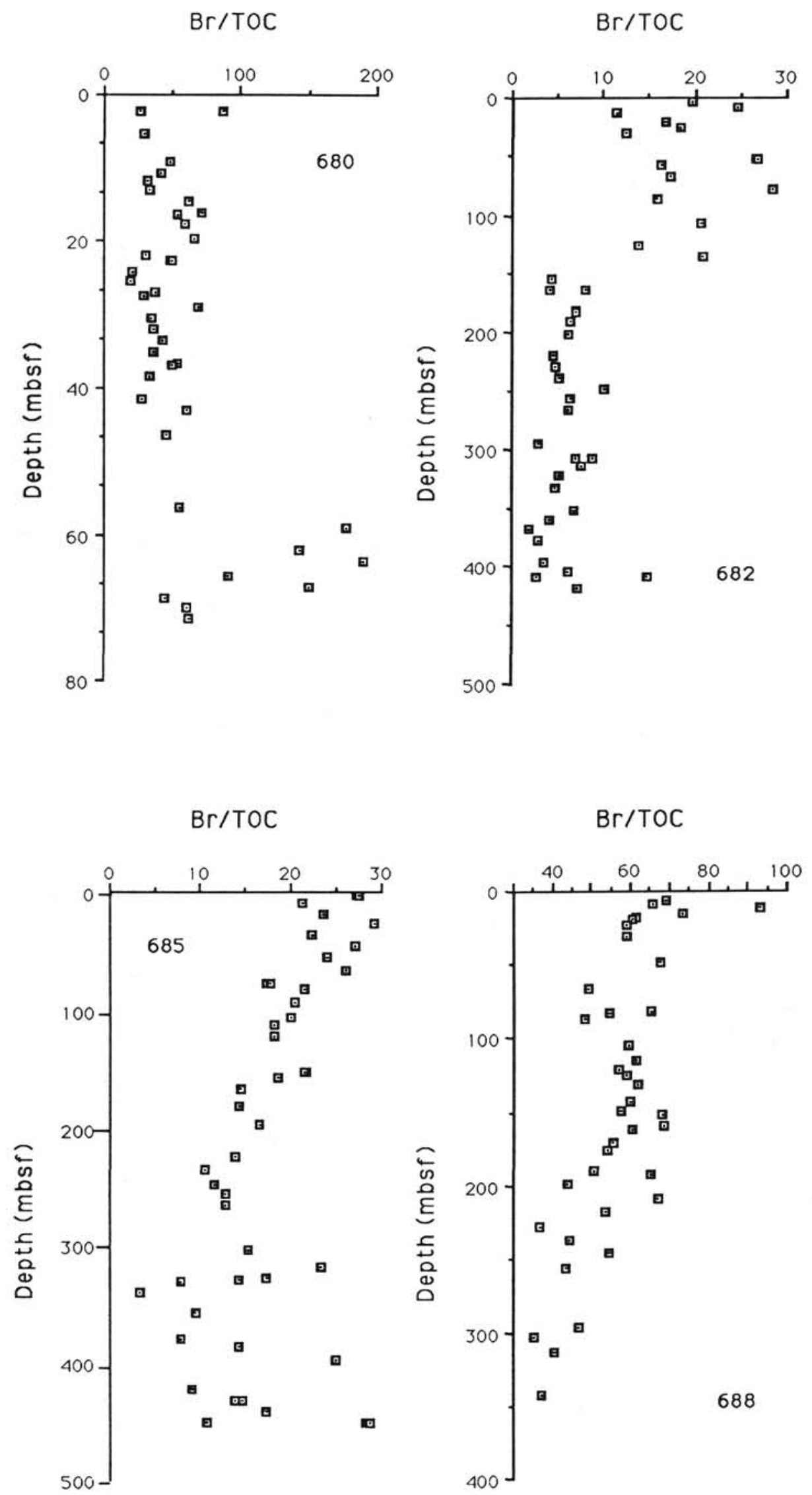

Figure 12. Downhole plots of ratios of TOC to bromine in sediments from Sites $680,682,685$, and 688. 

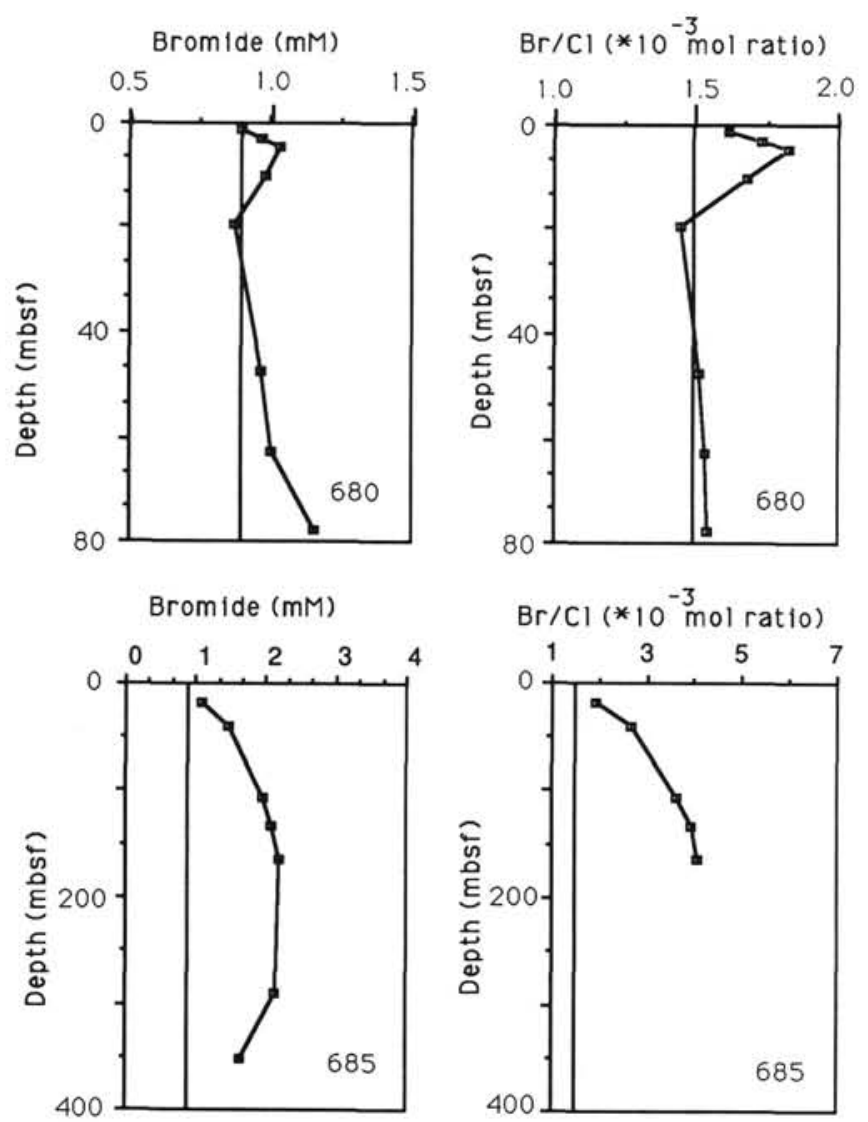

Bromide (mM)
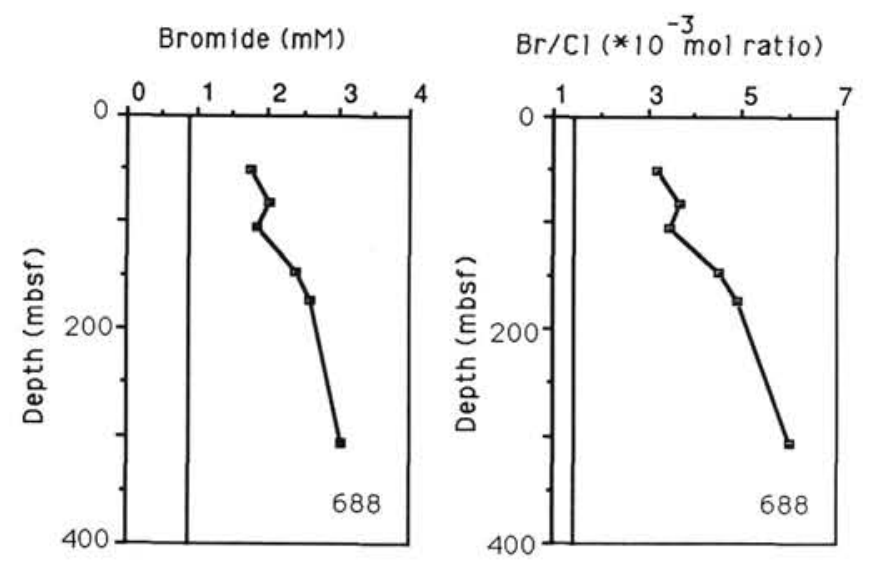

Figure 13. Plots of downhole variations in dissolved bromide with depth for Sites 680,685 , and 688 , normalized for chlorinity. Solid lines denote values of seawater.

diagenetic origin and mobility of the bromide ion. Pedersen and Price (1980) predicted an increase in pore-water bromide on the basis of their observed decrease in the bromine/TOC ratios in sediments from the Panama Basin. However, they estimated that such an increase would not be detectable when compared with the high seawater bromide levels. An increase in dissolved bromide was measured by Presley and Culp (1973) in pore waters of Cariaco Trench sediments (DSDP Site 147). Dissolved bromide enrichments, which could also be attributed to diagenetic imprint, have been observed in Bransfield Strait, Antarctica (E. Suess, pers. comm., 1987). However, our results are the first (to our knowledge) to document an increase resulting from bromine mobilization during diagenesis of organic matter.
In light of these results, one can easily explain the observed depletion of bromine relative to organic carbon in the Peru margin sediments, and it is not surprising that the deepest sediments at Site 682 , which represent the oldest sediments studied here ( $>15 \mathrm{~m} . \mathrm{y}$.$) , show the highest bromine depletion$ relative to TOC.

\section{CONCLUSIONS}

Based on factor analysis of the detrital component, we observe an obvious and clear-cut effect of either dramatic changes in sea level or the dramatic tectonic evolution of the morphology of the Peru forearc region on the mass of detrital influx. Shallow-water sediments, recognized as such on the basis of sedimentological and paleontological evidence, are characteristic partly in the abundance of detrital material and in parameters related to diagenetic elements, i.e., in bromine, TOC, and iron sulfides. With reservations, we think that the suite of parameters analyzed here can be used to differentiate between different parts of the Peru forearc depositional environment. More promising approaches, however, include the investigation of organic matter character (Emeis and Morse, this volume) and the abundance of barium in the sediments.

In this study, we indicate the effect of depositional environments on barium accumulation in sediments. Site 680 , although similar in organic matter and opal contents to other sites $(688,685)$, does not show any barium enrichment over that supplied by the detrital load. This observation might be the result of differences in the water depths among the sites. Site 680 , being shallower than the other studied sites, does not allow for barium to be significantly enriched by the sinking organic opal-rich particles.

Results from the downhole distribution of dissolved and sedimentary barium give strong evidence for barium remobilization in sediments lacking interstitial sulfate, with subsequent re-precipitation of the upwardly diffusing barium in sediments not yet depleted in sulfate. These results confirm the occurrence of barium fronts previously observed in Gulf of California sediments by Brumsack (1986), which limits the usefulness of this element for paleoproductivity studies to sediments where sulfate is not depleted by microbial activity.

We were able to identify an age dependent bromine/TOC relationship for the sediments studied. The remineralization of organic matter to depths of several tens of meters leads to bromide accumulation in pore fluids. Because similar dissolved bromine distributions have been observed in other organic carbon-rich hemipelagic environments (Presley and Culp, 1973; E. Suess, pers. comm., 1987), we conclude that this must be a common diagenetic behavior for bromine in rapidly accumulating, organic-rich sediments. This is of particular interest because bromide was thought to behave conservatively, as chloride does, and as such was used as an indicator of concentration/dilution processes in marine sedimentary environments.

\section{ACKNOWLEDGMENTS}

P. Boothe and B. J. Presley (TAMU) made the INAA analyses possible, and B. J. Katz (Texaco, Houston) provided the Rock-Eval analyses for Site 688 . We gratefully acknowledge the analysis of dissolved barium by P. Stoffers (Kiel, Germany), technical support from the Ocean Drilling Program, and financial support from USSAC to K.-C. Emeis. Two anonymous reviewers and the ODP editorial help greatly improved the manuscript and our thinking.

\section{REFERENCES}

Ballesteros, M. W., Moore, G. F., Taylor, B., and Ruppert, S., 1988. Seismic stratigraphic framework of the Lima and Yaquina forearc basins, Peru. In Suess, von Huene, et al., Proc. ODP, Init. Repts., 112: College Station, TX (Ocean Drilling Program), 77-90. 
Bishop, J. K., 1988. The barite-opal-organic carbon association in oceanic particulate matter. Nature, 24:341-434.

Brongersma-Sanders, M., Stephan, K. M., Kwee, T. G., and de Bruin, M., 1980. Distribution of minor elements in cores from the southwest Africa shelf with notes on plankton and fish mortality. Mar. Geol., 37:91-132.

Brumsack, H. J., 1986. The inorganic geochemistry of Cretaceous black shales (DSDP Leg 41) in comparison to modern upwelling sediments from the Gulf of California. In Summerhayes, C. P., and Shackleton, N. J. (Eds.), North Atlantic Paleocenaography. Geol. Soc. Am. Spec. Publ., 21:447-462.

Brumsack, H. J., and Gieskes, J. M., 1983. Interstitial water traceelement chemistry of laminated sediments from the Gulf of California, Mexico. Mar. Chem., 14:89-106.

Calvert, S. E., and Price, N. B., 1983. Geochemistry of Namibian Shelf sediments. In Thiede, J., and Suess, E. (Eds.), Coastal Upwelling; Its Sediment Record, Vol. 1: New York (Plenum Press), 337-375.

Chan, L. H., Drummond, J. M., Edmond, J. M., and Grant, B., 1977. On the barium data from the Atlantic Geosecs expedition. DeepSea Res., 24:613-649.

Collier, R., and Edmund, J., 1984. The trace-element geochemistry of marine biogenic particulate matter. Progr. Oceanogr., 13:113-199.

Dehairs, F., Chesselet, R., and Jedwab, J., 1980. Discrete suspended particles of barite and the barium cycle in the open ocean. Earth Planet. Sci. Lett., 49:528-550.

Goldberg, E. D., and Arrhenius, G.O.S., 1958. Chemistry of Pacific pelagic sediments. Geochim. Cosmochim. Acta, 13:153-212.

Howarth, R. J., and Sinding-Larsen, R., 1983. Multivariate analysis. In Howarth, R. J. (Ed.), Statistics and Data Analysis in Geochemical Prospecting: Amsterdam-Oxford-New York (Elsevier), Handbook of Expl. Geochem., Vol. 2, 207-289.

Jumars, P. A., Altenbach, A. V., De Lange, G. J., Emerson, S. R., Hargrave, B. T., Muller, P. J., Prahl, F. G., Reimers, C. E., Steiger, T., and Suess, E., in press. Transformation of seafloorarriving fluxes into the sedimentary record. In Berger, W. H., Smetacek, V., and Wefer, G. (Eds.), Productivity of the Ocean: Present and Past: Dahlem Workshop.

Koide, M., and Goldberg, E. D., 1981. Transuranic elements in two coastal marine sediments off Peru. Earth Planet. Sci. Lett., 57:263-277.

Kulm, L. D., Schrader, H., Resig, J. M., Thornburg, T. M., Masias, A., and Johnson, L., 1981. Late Cenozoic carbonates on the Peru continental margin: Lithostratigraphy, biostratigraphy, and tectonic history. Geol. Soc. Am. Mem., 154:468-508.

Murray, D. W., 1987. Spatial and temporal variations in sediment accumulation in the central tropical Pacific [Ph.D. dissert.]. Oregon State University, Corvallis.
Pedersen T. F., and Price, N. B., 1980. The geochemistry of iodine and bromine in the sediments of Panama basin. J. Mar. Res., 38:397-411.

Presley, B. J., 1971. Techniques for analyzing interstitial water samples. Part I: Determination of selected minor and major inorganic constituents. In Winterer, E. L., Riedel, W. R., et al., Init. Repts. DSDP, 7: Washington (U. S. Govt. Printing Office), 1756.

Presley, B. J., and Culp, J., 1973. Interstitial water studies, Leg 15. In Heezen, B. C., MacGregor, I. D., et al., Init. Repts. DSDP, 20: Washington (U.S. Govt. Printing Office), 805-809.

Price, N. B., Calvert, S. E., and Jones, P. G., 1970. The distribution of iodine and bromine in the sediments of the southwestern Barents Sea. J. Mar. Res., 28:22-34.

Price, N. B., and Calvert, S. E., 1977. The contrasting geochemical behaviors of iodine and bromine in recent sediments from the Namibian shelf. Geochim. Cosmochim. Acta, 41:1769-1775.

Puchelt, H. 1972. Barium. In Wedepohl, K. H. (Ed.), Handbook of Geochemistry, Vol. II-3: New York-Heidelberg-Berlin (SpringerVerlag).

Romankevich, E. A., 1984. Geochemistry of Organic Matter in the Ocean: New York-Heidelberg-Berlin-Tokyo (Springer-Verlag).

Schmitz, B., 1987. Barium, equatorial high productivity and the northward wandering of the Indian continent. Paleoceanography, 2:63-77.

Scheidegger, K. F., and Krissek, L. A., 1983. Zooplankton and nekton: natural barriers to the seaward transport of suspended terrigenous particles off Peru. In Suess, E., and Thiede, J. (Eds.), Coastal Upwelling-Its Sediment Record, Part A: New York (Plenum Press), 303-333.

Suess, E., Kulm, L. D., and Killingley, J. S., 1987. Coastal upwelling and a history of organic-rich mudstone deposition off Peru. In Brooks, J., and Fleet, A. J. (Eds.), Marine Source Rocks. Geol. Soc. Am. Spec. Publ., 26:181-197.

Suess, E., von Huene, R., et al., 1988. Proc. ODP, Init. Repts., 112: College Station, TX (Ocean Drilling Program).

von Huene, R., and Miller, J., 1988. Migrated multichannel seismicreflection records across the Peru continental margin. In Suess, von Huene, et al., Proc. ODP, Init. Repts., 112:109-124.

Wedepohl, K. H. 1970. Environmental influences on the chemical composition of shales and clays. In Ahrens, L. H., Press, F., Runcorn, S. K., and Urey, H. C. (Eds.), Physics and Chemistry of the Earth: Oxford (Pergamon Press), 307-333.

Date of initial receipt: 27 October 1988

Date of acceptance: 5 May 1989

Ms 112B-200 